\title{
IMPLEMENTASI PROGRAM PENGEMBANGAN PRODUK UNGGULAN DAERAH KAIN TENUN KHAS DAERAH PALEMBANG
}

\author{
Bainil Yulina ${ }^{1}$, Evada Dewata ${ }^{2}$, Slamet Widodo $^{3}$, Eka Susanti $^{4}$, Pridson Mandiangan ${ }^{5}$ \\ Politeknik Negeri Sriwijaya \\ Jalan Srijaya Negara Bukit Besar Palembang, 30139 \\ byulina@gmal.com ${ }^{1}, \underline{\text { evada_polsri@yahoo.co.id }}{ }^{2}$,slamet_widodo2003@yahoo.com ${ }^{3}$, \\ eka_susanti7644@yahoo.com ${ }^{4}$.primaputramando@gmail.com ${ }^{5}$
}

\begin{abstract}
Abstrak
Program Pengembangan Produk Unggulan Daerah Kain Tenun khas Palembang adalah kegiatan penerapan IPTEK dari Politeknik Negeri Sriwijaya yang didanai melalui Dirjen Diktisebagai upaya pengembangan budaya aset daerah Palembang berupa kain tenun tajung ,blongsong dan jupri . Kegiatan ini bertujuan untuk memacu dan mengembangkan kaintenun unggulan khas daerah Palembang sebagai usaha peningkatan kualitas, kuantitas produk, distribusi dan pemasaran. Permasalahannya KUBe Griya Kain Tuan Kentang belum mampu memproduksi secara maksimal dikarenakan pembuatan tenun tersebut masih manual dan terbatasnya tenaga pembuat Kain tenun tersebut .Pemasaran yang masih terbatas belummemanfaatkanteknologiinformasidan masih manual,manajemen pengelolaan baik keuangan maupun SDM belum dapat mengimbangi banyaknya pesanan dari pelanggan. Bentuk kegiatan yang dilakukan bertujuan agar kain tenun khas Palembang mudah dikenal, mudah didapat dan berdaya saing tinggi.. Kegiatan PPPUD merupakan pelaksanaan tahun pertama selama 3 tahun Prioritas pemecahan masalah tahun pertama perbaikan proses produksi berupa penerapan mesin semi otomatisasi sistem kendali alat tenun Penerapan E-Commerce dan Program Aplikasi Persediaan dan Penjualah berbasis Komputer, Luaran yang dihasilkan berupa teknis teknologi, pendidikan teknologi, manajemen keuangan, manajemen produksiTarget capaian tahunan berupa peningkatan nilai asset UMKM, peningkatan nilai omzet UMKM, pertemuan ilmiah,publikasi ilmiah di jurnal nasional, jurnal internasional dan media masa serta buku ajar.
\end{abstract}

Kata kunci : Kain Tenun khas daerah ,UMKM, KUBe, PPPUD

\section{PENDAHULUAN}

Palembang merupakan salah satu kota yang besar dan maju di Indonesia. Buktinya beberapa perhelatan acara berskala nasional dan internasional Contohnya SEAGAMES, Asean University Games, Islamic Solidaity Games, MTQ internasional Asean Games Dengan perhelatan yang seperti ini juga Palembang sering dinobatkan sebagai kota MICE (Meeting Incentive Convention Exhibition). Palembang tidak ada kebun karet dan batubara, tapi memiliki kebudayaan dan kerajinan. Oleh karena itu harus

\begin{tabular}{l|l} 
Ekonomi, Sosial, dan Budaya & 1303
\end{tabular} 
dimaksimalkan. Pertumbuhan ekonomi di Palembang terus mengalami peningkatan yang signifikan. Pada tahun 2012 perekonomian di Palembang tumbuh $6,4 \%$ yang ditopang dengan jumlah penduduk sekitar 1,7 juta jiwa.Berdiri sejak tahun 1960an sentra produksi kain tenun dan tuankentang kecamatan seberang ulu I Palembang sudah keseluruhan selain pasar produk kain di Bumi Sriwijaya ini sudah merambat hingga ke negara tetangga seperti Brunei dan Malaysia omset pengrajin puluhan juta rupiah perbulan. Kelurahan tuan kentang terletak di kawasan pusat kerajinan Palembang dan aktivitas produksi dilakukan dirumah masing-masing. Hasil karya mereka dijual dengan cara memajang produk kain diruang tamu masingmasing. Tahun 2005, kawasan diresmikan pemerintah Palembang sebagai sentra produksi kain tenun Palembang, yaitu tajung, blongsong dan jupri. Awalnya menggunakan alat tenun gendong yang memproses cukup lama selang 15 hari untuk 1 kain.. Produk kain tenun tajung blongsong, tenun tajung sutra. Cotton merseni, blongsong, blongket dan jumputan produksi fesyen berbahan kain tenun berupa busana muslim, busana pesta, busana adat, kemeja, rok dan blus. Ahmad Habibi pemimpin Griya sejak tahun 2005 mengatakan harga jual sarung tajung $\mathrm{Rp} 180.000$ - Rp 250.000, brongket dan slendang $\mathrm{Rp} 500.000$, bahan dasar permeter Rp 40.000 dan omzet 50juta perbulan. Pegawai KUBe terdiri dari 29 orang, yaitu pada bagian administrasi 4 orang dan pengrajin 25 orang. 1

Melalui tinjauan Tim pelaksana ke lapangan dikatakan pihak UMKM bahwa mereka mencoba mempertahankan dan mengembangkan usaha kain tradisional khas Palembang sebagai suatu warisan budaya. Dengan tetap memproduksi kain tajung , Blongsong, Jupri dan Jumputan. mengembangkan motif serta desain yang inovatif agar dapat mengikuti perkembangan zaman dan menumbuhkan rasa cinta dan bangga pemakainya tanpa meninggalkan unsur-unsur budaya lokal sebagai kain tenun khas Palembang. maka perlu adanya pembinaan dan pendampingan seperti yang dilakukan Tim pelaksana bermaksud untuk mengembangkan usaha kain tenun Khas daerah Palembang, sekaligus dalam rangka pemberdayaan masyarakat sekitar dan peningkatan kualitas dan kuantitas produk tenun agar dapat memenuhi kebutuhan pasar. Disisi lain Tim Pelaksana telah melaksanakan penelitian yg menghasilkan patent dengan diadakannya mesin semi otomatisasi untuk membantu produksi tenun yg lebih efisien baik dari waktu pengerjaan dan kualitas produk yg direncanakan untuk diimplementasikan dan juga penerapan dari hibah penelitian berupa rancangan E-Commerce dan Komputerisasi pembelian dan penjualan produk.

Kawasan Tuan Kentang adalah kawasan daerah pengrajin kain tenun dan jumputan khas Palembang. Dengan jumlah pengrajin lebih dari 100 Tuan kentang menjadi daerah yang sangat memiliki potensi untuk dijadikan destinasi wisata Palembang. Untuk mewujudkan itu Pemerintah Palembang melalui dinas perindustrian dan Bank Indonesia membangun gedung yang akan digunakan sebagai pusat aktifitas pengrajin tenun dan jumputan yang ada di Tuan kentang. Untuk memudahkan meningkatkan kualitas produk, menjual hasil produk dan mensejahterakan Pengrajin Tenun dan Jumputan membentuk Kelompok Usaha Bersama (KUBe) Griya Tuan Kentang yang difasilitasi BI. Tercatat pada tanggal 25 Januari 2017 KUBe Griya Kain Tuan Kentang berdiri dengan membina 25 anggota yang merupakan pengrajin kain tenun dan jumputan, memfasilitasi anggota untuk menjualkan produk di galeri dengan kualitas produk yang terbaik.KUBe memiliki galeri yang menjual produk anggota.produk yang dijual diantaranya Tenun tajung, Blongsong dan Jupri memiliki banyak variasi produk daintaranya sarung tajung, bahan tajung, blongket, blongket tabur emas, dan kombinasi jumputan dan tenun.

Program Pengembangan Produk Unggulan Daerah merupakan salah satu skim kegiatan Pengabdian Kepada masyarakat Direktorat Jendral Pendidikan Tinggi yang memfasilitasi dana kegiatan dengan tujuan meningkatkan pengetahuan dan keterampilan UMKM yang berperan memacu pertumbuhan produk unggulan daerah untuk pasar dalam negeri dan pasar global mengembangkan 
proses Link and match antar perguruan tinggi, industri, Pemda dan masyarakat luas, telah memotivasi tim pelaksana untuk meningkatkan kualitas UMKM khusunya Kube Griya Kain Tuan Kentang ini. Setelah Tim pelaksana melakukan observasi ke KUBe Griya Kain Tuang Kentang, dapat melihat produk yang dihasilkan berkelas dan unik dari kualitas dan desain dengan harga yang strategis dapat dijangkau dari semua kalangan ekonomi masyarakat ,kondisi inilah merupakan peluang bagi UMKM tersebut.Keterbatasan infrastruktur proses produksi serta panjangnya tahapan pembuatan Kain tenun dan kurangnya sumber daya manusia yang menekuni kerajinan terutama pembuat motif dengan sungkit mengakibatkan terbatasnya desain dan motif kain yang dihasilkan . dengan adanya Mesin Semi otomatisasi sistem kendali alat tenun membantu mempermudah pembuatan kain tenun menjadi lebih cepat yang biasanya 7 hari menjadi 3 hari dalam memproduksi 1 selendang. Tim Pelaksana merencanakan pemberdayaan alat kerup merseni semi otomatis yang merupakan hasil penelitian dosen polsri yang juga anggota tim pelaksana pada penelitian hibah bersaing tahun 2016. Jangkauan pemasaran Produk kain tenun yang sudah dibuat didistribusikan Griya KainTuan Kentang, selain itu kepasar 16 ilir dan ketoko/outlet atau kebutik.,selain pembelian langsung melayani juga pengiriman pesanan keluar kota,tetapi pemasaran dan distribusi masih terbatas dikarenakan sering mengikuti pameran tetapi terbatas di dalam kota. Kurangnya memanfaatkan teknologi informasi secara maksimal, kondisi ini akan berakibat terbatasnya omzet penjualan. Sudah menggunakan Face book dan instagram tetapi pemasaran belum on line, atau begitu juga untuk pencatatan pembelian dan penjualan masih dicatat secara manual. Pada saat sekarang UKM tersebut sudah mempunyai 1 perangkat komputer tetapi belum digunakan dikarenakan belum adanya program aplikasi dan SDM yg dapat mengoperasikannya. Manajemen usaha yang digunakan masih bersifat konvensional, pembukuan masih bersifat konvensional belum ada penyusunan laporan keuangan berbasis prinsip akuntansi sehingga masih mengalami kesulitan menghitung keuntungan produk secara rinci. Sumber daya manusia manusia pada KUBe Griya kain Tuan Kentang adalah masyarakat disekitar lokasi industri yang dapat menyerap tenaga kerja tetapi kurangnyakemampuan SDM dalam mendesain motif dan kombinasi warna.Khusus di Griya Kain Tuan Kentang Palembang.

\section{METODE}

Metode pendekatan yang digunakan dilakukan dengan beberapa tahapan , dalam rangka mencari tahu permasalahan maka perlu dilakukan inventarisasi.dalam pola ini sudah dilakukan survey pendahuluan ke Lokasi mitra, selanjutnya dilakukan inventarisasi mengenai data-data UMKM yang akan didampingi dan pengelompokan klasifikasi jenis permasalahan yang dihadapi Setiap kegiatan akan selalu didiskusikan antara ketua pelaksana dan pihak KUBe Griya Kain Tuan Kentang serta pengrajin. Pendampingan dilakukan sebagai saran monitoring dan memandu pengelola UMKM untuk menerapkan teori yang diperoleh, Secara spesifik kegiatan meliputi konsultasi dan bimbingan dalam mengimplementasikan teknologi mesin semi otomatisasi, konsultasi dan bimbingan dalam mengoperasikan $E$ Commerce dan Program aplikasi akuntansi. Pendampingan dilakukan dalam bentuk kunjungan lapangan ke UMKM untuk memantau secara intensif selama 2 bulan . Pendampingan tahap awal tim pelaksana memfokuskan pada penjelasan tentang materi pelatihan. Pada pendampingan kedua mengoreksi bilamana ada kesalahan atau kekurang pahaman dalam mengoperasikan mesin dan E-Commerce dan program aplikasi. Pendampingan ketiga Tim Pelaksana melanjutkan pengenalan dan penerapannya. Pendampingan keempat , selain memonitor dan memandu pengelola UMKM mengoperasikan mesin, $E$ Commerce.dan Keuangan, Tim pelaksana mengevaluasi kondisi materi pelatihan dan juga penerapannya dalam pengelolaan usaha oleh UMKM tersebut

Untuk mengetahui keberhasilan dari setiap kegiatan yang telah dilaksanakan, maka 
akan dilakukan penilaian melalui tahapan Kinerja Paket Teknologi Indikator keberhasilan akan dinilai dari efisiensi proses pembuatan model tenun tajung Palembang dalam bentuk peningkatan kualitas produksi kain tenun khas daerah kepada pengrajin . Pemeriksaan kualitas model tenunan akan dilakukan secara subjektif dengan melakukan uji evaluasi hasillkain tenun yang diberikan pengrajin kepada calon pengrajin baru. Penilaian ini akan dilaksanakan oleh pihak yang berkompeten, dalam hal ini calon pembeli kain tenun yang sudah memiliki pengalaman dalam memberikan penilaian terhadap kompetensi pengrajin kain tenun Palembang..Selanjutnya akan diberikan Pelatihan mengoperasikan mesin otomatisasi ,e-Commerce, dan program aplikasi - Indikator kinerja dilakukan dengan memberikan evaluasi kepadapoin-poin: Langkah-langkah membuat content produk kain tenun dengan aplikasi program komputer, perawatan dan perbaikan mesin tenun., Terakhir akan dibuat laporan kegiatan. Indikator kinerja dievaluasi melalui seminar tingkat lembaga dengan poin-poin: Format laporan, Substansi serta tata tulis.

Dalam pelaksanaan program, mitra ikut berpartisipasi dan terlibat pada kegiatan Mitra bersamaTim pengusul bersama-sama merencanakan kegiatan dan Jadwal kegiatan..Mitraa bersedia menyediakan tempat untuk pelatihan ,Tim pelaksana memberikan sosialisasi dan pelatihan pemakaian mesin semi otomatisasi Kain tenun, pengenalan dan penggunaan program E-Commerce,serta

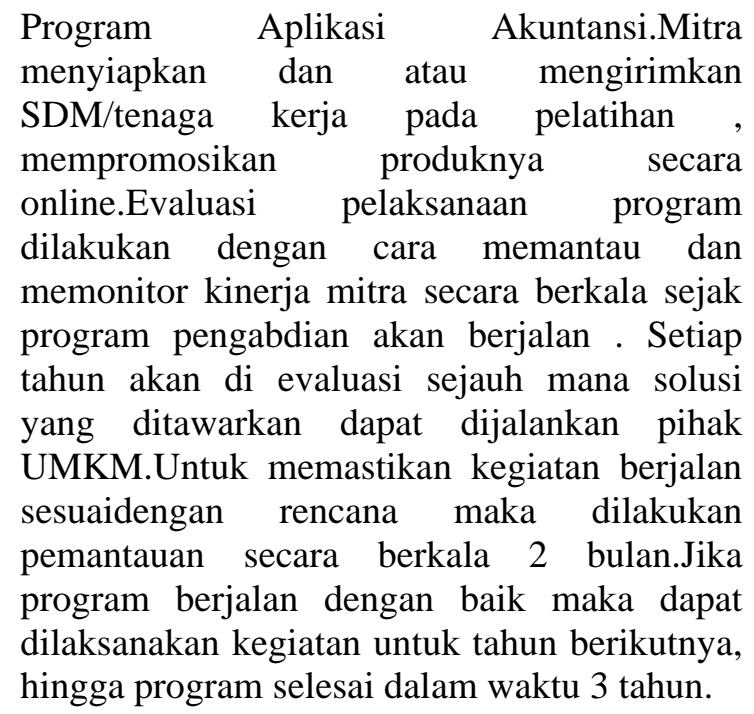

\section{HASIL DAN PEMBAHASAN}

Pelaksanaan Tahun ke 1 menghasilkan luaran berupa MesinTenun Semi Otomatisasi, Program E-Commerce, Program Akuntansi Persediaan dan Penjualan berbasis komputer produk Kain tenun.

Dalam pelaksanaan Program Pengembangan Produk Unggulan Daerah (PPPUD)Negeri Sriwijaya disusun rencana kerja yang disesuaikan dengan metode pendekatan melalui tahapan Implementasi program PPPUD yang didahului dengan sosialisasi kegiatan, selanjutnya dilakukan kegiatan melalui tahapan persiapan yaitu Sosialisasi

Kegiatanyaitu menginformasikan kepada Tim dan Kube Griya Tuan Kentang kegiatan PPPUD yang akan dilakukan, jadwal kegiatan dan lain-lain. 

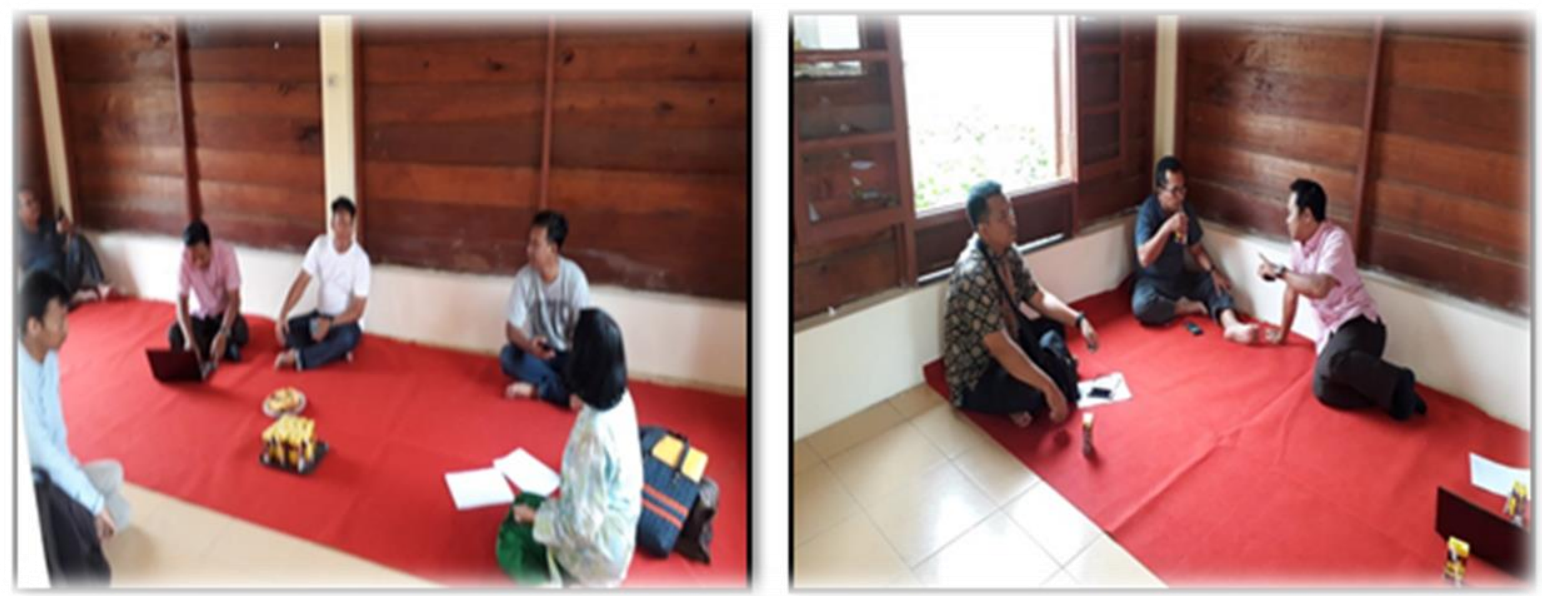

Gambar1.Sosialisasi dan koordinasi kegiatan oleh Tim dan pengurus Kube Griya Kain Tuan Kentang

Tahap Persiapan Tim pelaksana yang terdiri dari 4 orang Dosen dan 4 orang mahasiswa, dibagi dan diberi tanggung jawab sesuai dengan kompetensi, yaitu yang diprioritaskan untuk tahun ke 1 , mesin semi otomatisasi
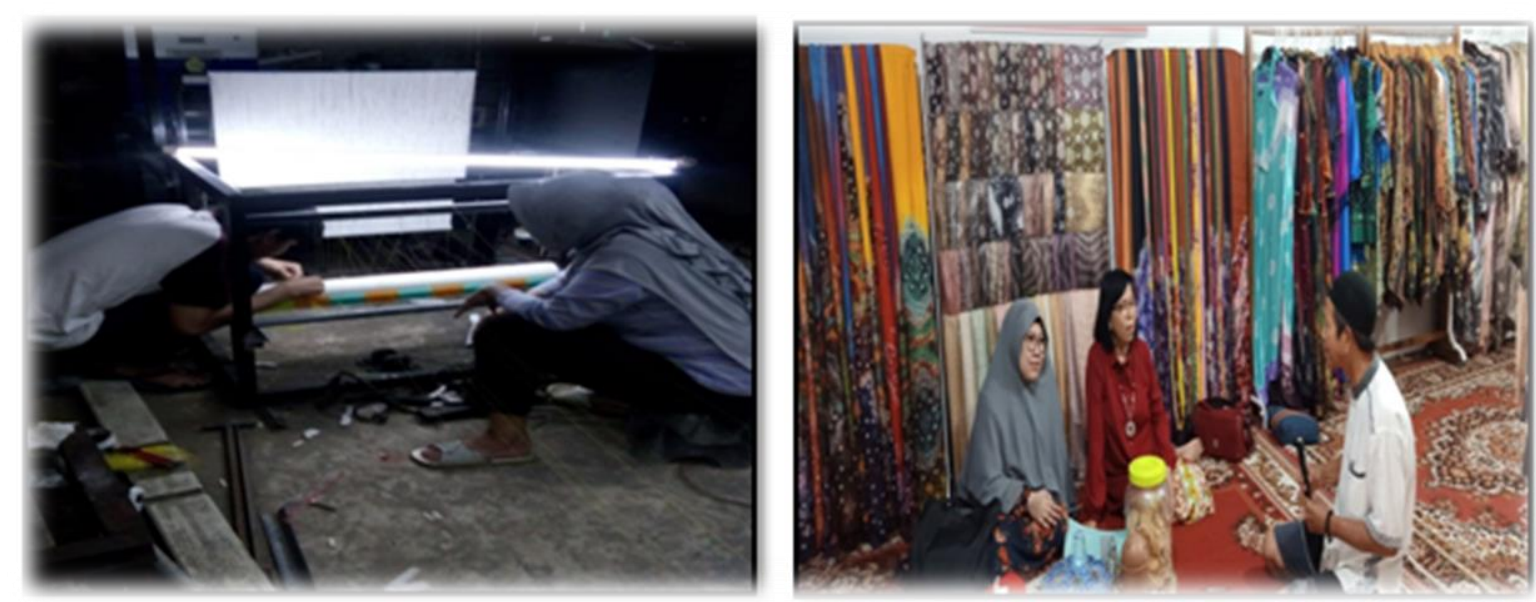

Gambar 2.Persiapan alat MesinTenun Semi otomatisasi dan Pengumpulan data UMKM

Luaran yang dihasilkan berupa Mesin Tenun Semi Otomatisasi sudah selesai disiapkan, 


\section{IF|KM \\ CBRI}

Prosiding PKM-CSR, Vol. 2 (2019)

e-ISSN: $2655-3570$
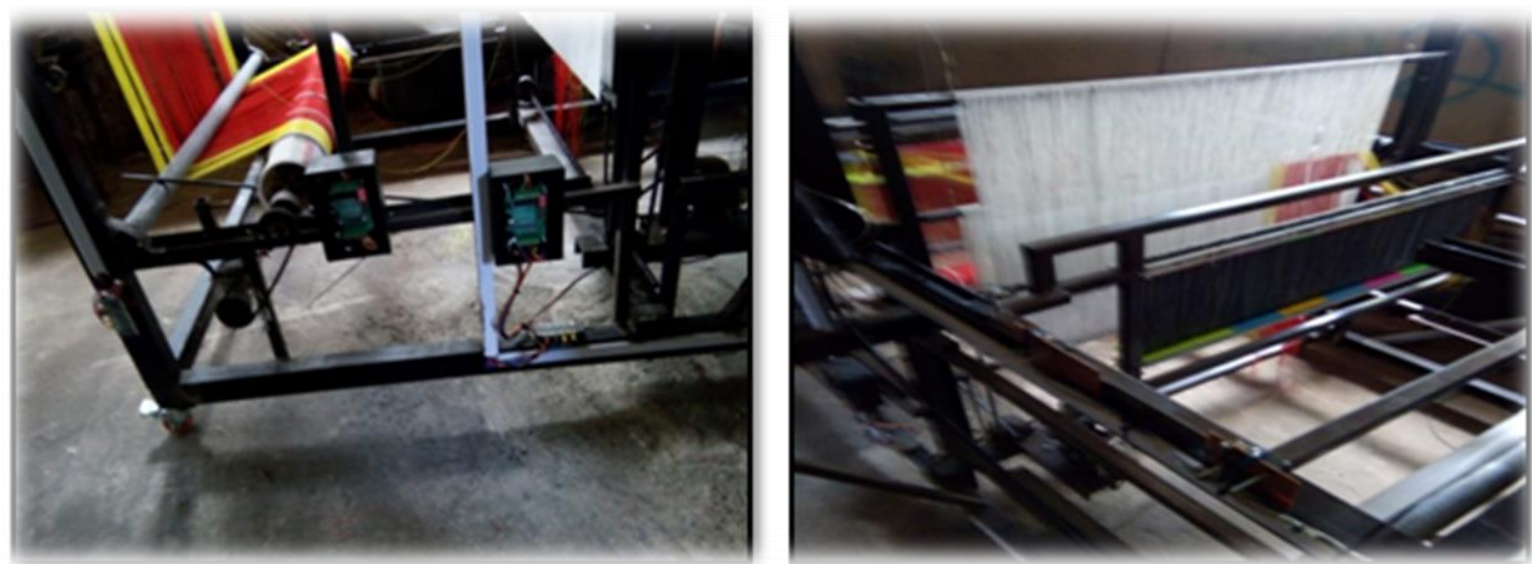

Gambar 3.Mesin Tenun Semi Otomatisasi

\section{Program E-Commerce}
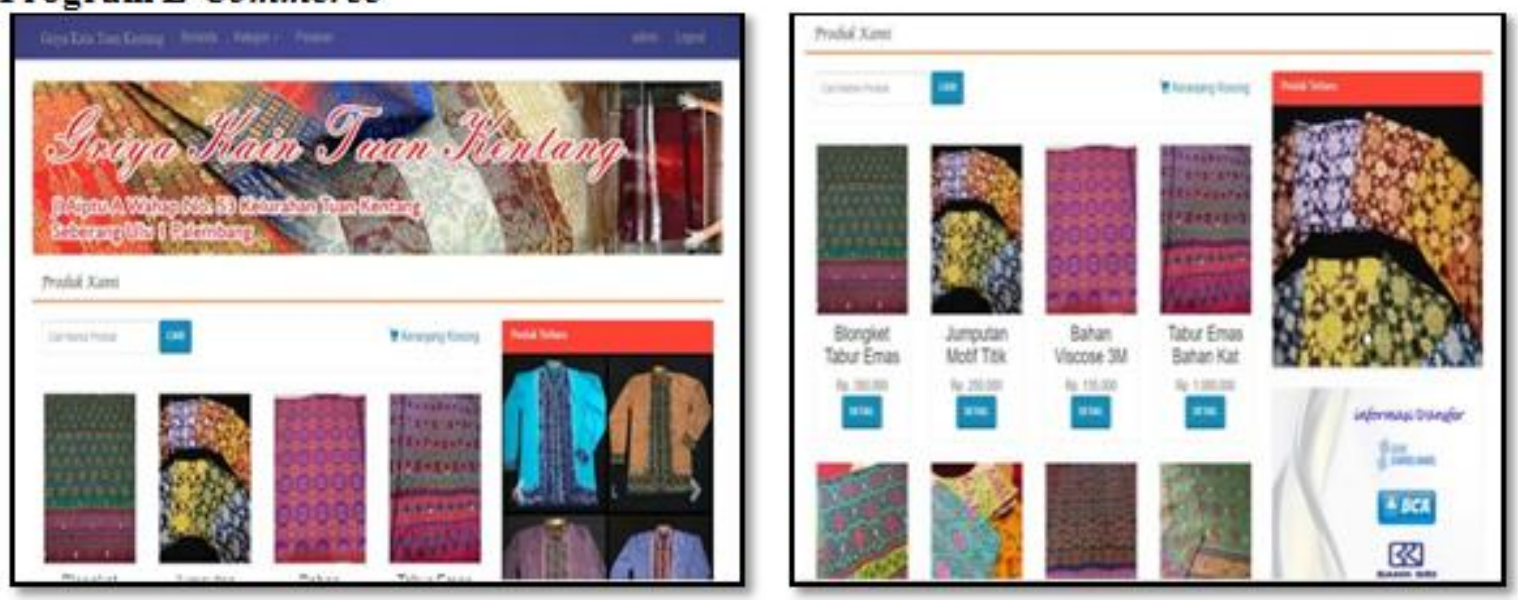

Gambar 4.Tampilan Halaman Pelanggan dan kategori

Program Aplikasi Persediaan dan Penjualan bebasis Komputer.
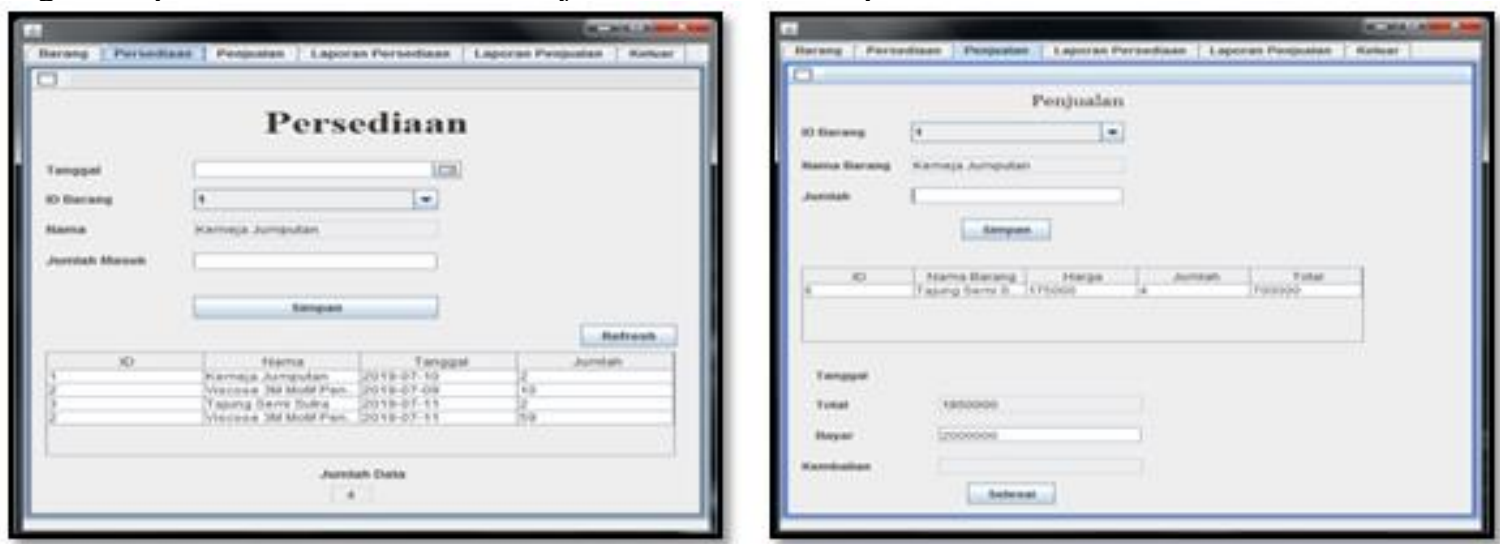

Gambar 5: Tampilan Halaman Persediaan

Sebagai bentuk pertanggungjawaban pelaksanaan kegiatan Pengabdian Kepada Masyarakat dan juga Tim Pelaksana memanfaatkannya sebagai momen penting untuk mempromosikan kegiatan dan produkjasa yang dihasilkan, maka Tim Pelaksana

Ekonomi, Sosial, dan Budaya 1308 
mengirimkan artikel ke Forum Ilmiah dalam kegiatan Seminar Nasional hasil Pengabdian Masyarakat di Surabaya, tanggal 23 - 25 Oktober 2019 yang akan menghasilkan Prosiding dan Jurnal Ilmiah. Pada saat ini menunggu proses review yang akan diumumkan pertengan bulan Agustus 2019.Selain itu disiapkan artikel untuk
InCOGITE Konferensi Internasional tentang Global Inovasi dan Trend Ekonomi yang diadakan di Universitas Pelita Harapan Tangerang pada tanggal 7 November 2019. Kegiatan lainnya Tim pelaksana sudah mempersiapkan video kegiatan ,

Hasil penerapan Teknologi membawa nilai tambah UMKM tertera pada tabel 1

Tabel 1.Nilai tambah dari penerapan Teknologi pada UMKM

\begin{tabular}{|l|l|}
\hline \multicolumn{1}{|c|}{ Teknologi } & \multicolumn{1}{c|}{ Nilai tambah } \\
\hline Mesin Tenun Semi otomatis & Pengerjaan kain tenun semakin cepat dari 7 hari menjadi 4 \\
& hari \\
Program E-commerce & Pemasaran produk semakin luas jangkauan, semakin \\
& banyak pelanggan yang mengetahui. \\
Prog.Persediaan dan Persediaan & $\begin{array}{l}\text { Proses dan Pelaporan persediaan dan penjualan produk } \\
\text { kain tenun diketahui lebih cepat dan terdokumentasi. }\end{array}$ \\
\end{tabular}

Sumber : Hasil Pengolahan data

Tabel2.Dampak Kegiatan PPPUD bagi KUBe Griya Kain Tuan Kentang

\begin{tabular}{|l|l|}
\hline \multicolumn{1}{|c|}{ Indikator Kegiatan } & Adanya Program PPPUD \\
\hline Pengetahuan TeknologiMeningkat sebesar 15\% \\
Jumlah Asset UMKMMeningkat sebesar $15 \%$ \\
Jumlah Tenaga KerjaMeningkat sebesar $15 \%$ \\
\hline
\end{tabular}

Sumber : Hasil Pengolahan data

\section{PEMBAHASAN}

\section{Peranan Perguruan Tinggi pada Strategi Pemberdayaan UMKM}

Tanpa memiliki mentor bisnis,
UMKM akan kesulitan dalam
mengembangkan bisnisnya lebih besar
lagi. Pengetahuan seputar bisnis menjadi
terbatas dan dia akan kesulitan dalam
melakukan inovasi produkm makadengan
memiliki mentor bisnis yang bisa
membimbing UMKM lebih baik lagidalam
menjalankan usaha.Memiliki mentor bisnis
tidak berarti mengharuskan untuk
bersekolah bisnis atau bergabung dengan
pelatihan eksklusif khusus pebisnis.
Melalui Program Pengembangan Produk
Unggulan daerah (PPPUD) DIKTI,
Politeknik Negeri Sriwijaya melakukan
pemberdayaan UMKM.melakukan

pembinaan terhadap UMKM termasuk melakukan pembinaan dan pemberian fasilitas kepada UMKM. Memberikan sebuah paket teknologi berupa alat tenun mesin semi otomatis dengan model pelatihan pembuatan tenun tradisional dan penggunaan aplikasi komputer $e$ Commerce serta Program Aplikasi untuk transaksi pembelian dan penjualan berbasis komputerisasi

Berdasarkan data yang diperoleh dari Pimpinan Kelompok Usaha Griya Kain Tuan Kentang sebagai wadah yang berkumpulnya para pemilik sekaligus pengrajin, maka sesuai dengan indikator penilaian kegiatan PPPUD maka diperoleh data peningkatan nilai untuk pengetahuan, jumlah asset dan omzet penjualan untuk tahun pertama sebesar 15 persen, ini 
menunjukkan keberhasilan kegiatan PPPUD yang diprogramkan.

\section{Penerapan Teknologi pada UMKM}

$\begin{array}{llr}\begin{array}{l}\text { Permasalahan } \\ \text { berhubungan }\end{array} & \text { UMKM } & \text { yang } \\ \text { dengan } & \text { sulitnya }\end{array}$
mendistribusikan barang. Salah satu faktor yang menyebabkan pendistribusian barang UMKM kurang meluas karena pengusaha belum melakukan pemasaran online. Mungkin, beberapa pelaku UMKM sudah memasarkan produknya secara online melalui media sosial, situs marketplace, dan lain-lain, akan tetapi dalam prakteknya masih kurang maksimal. Sehingga hasil yang didapatpun kurang maksimal. Hal utama harus dilakukan pengusaha UMKM adalah memilih saluran pemasaran online yang tepat, lalu fokus memasarkan dalam saluran tersebut, dan terus mengoptimalkannya dengan memasarkan produknya melalui instagram. Memang tidak ada salahnya memasarkan produk tersebut ke saluran lain, misalnya Facebook atau situs markeplace, namun sebagai permulaan, sebaiknya focus memasarkan di satu saluran saja. Lalu, lakukan optimasi secara berkala agar pemasaran di saluran tersebut menghasilkan peningkatan konversi.

Banyak yang tidak sadar jika pembukuan secara manual menjadi permasalahan UKM yang cukup serius. Pembukuan secara manual ini rawan terjadinya kehilangan, kerusakan, dan bahkan kesalahan rekap, sehingga pengusaha tidak menganalisa hasil penjualannya secara tepat. Misalnya, jika laporan penjualan pada hari tertentu tibatiba hilang, maka laporan penjualan keseluruhanpun akan amburadul. Padahal, pembukuan yang baik adalah kunci evaluasi bisnis yang memadai. Dengan pembukuan yang baik, maka analisa penjualan usaha tentunya akan menjadi leibh tepat sebagai pertimbangan untuk mengambil keputusan selanjutnya.

Selain itu, pembukuan yang baik juga menjadi syarat wajib untuk semua pengusaha yang ingin meminjam modal usaha kepada bank. Untuk mengatasi permasalahan ini, perlu diatur kembali cara melakukan pembukuan usaha pada setiap harinya. Tinggalkan cara manual dan mulailah melakukan pembukuan secara otomatis dengan bantuan software. Teknologi tradisional masih menggunakan sistem produksi standar dan peralatan yang diguanakan tidak banyak, serta tenaga kerja yang dimiliki kurang berkualifikasi, pada teknologi transisi sistem produksi juga masih standar dengan penggunaan peralatan sederhana sehingga modern dan tenaga kerja yang kurang berkualifikasi. Penerapan teknologi yang cenderung pada karya akan memberikan porsi terhadap tenaga kerja lebih besar dari proporsi keuntungan bagi perusahaan, sedangkan penggunaan teknologi pada modal akan memberikan bagian kepada perusahaan lebih besar (Sukandar, 2000). Pemilihan teknologi yang akan digunakan berkaitan dengan skala usaha, jenis usaha, kemampuan biaya, kemampuan sumber daya manusia, serta kebutuhan atau keinginan pelanggan (Sa'id dan Intan, 2001). Penggunaan mesin ini selain bertujuan meningkatkan efisiensi tenaga kerja juga bertujuan untuk meningkatkan kualitas produk hasil olahan. Penggunaan mesin dalam proses produksi juga berimbas pada berubahnya biaya produksi, sehingga dapat merubah profitabilitas atau kemampuan sebuah usaha.

Dalam meningkatkan daya saing bisnisnya, hambatan UMKM sering mengalami kendala dalam melakukan inovasi produk. Saat ini jumlah produk UKM yang mampu menembus pasar internasional masih sangat sedikit sekali. Rendahnya daya saing produk dan jika dihubungkan dengan harga yang ditawarkan, produk UKM Indonesia masih jauh dari kualitas yang ditawarkan produk luar negeri. Untuk meningkatkan daya saing produk, para pelaku UKM harus lebih kreatif dan inovatif dalam memproduksi barang. Agar produk UMKM dilirik, maka menawarkan produk inovatif yang berbeda dengan produk sejenis lainnya dalam melakukan inovasi 
produk, maka haruslah rajin mencoba melakukan inovasi produk dengan menerapkan formula atau cara produksi yang baru.

\section{KESIMPULAN}

1. Politeknik Negeri Sriwijaya sebagai Perguruan Tinggi yang mendapat dukungan Dirjen Dikti telah berperan mendukung peningkatan kualitas daya saing UMKM dalam rangka mempersiapkan masyarakat atau UMKM menghadapi Era Industri 4.0 melalui Hibah Program Pengembangan Produk Unggulan Daerah ( PPPUD) Kain Tenun Palembang .

2. Bentuk Dukungan yang diberikan Perguruan Tinggi berupa Penerapan mesin tenun semi otomatisasi, penerapan program E-commerce, Program persediaan dan penjualan berbasis komputer.

\section{UCAPAN TERIMA KASIH}

Terima kasih pada semua pihak terutama kepada Dirjen Dikti yang telah memberikan kesempatan kepada Tim pelaksana dengan lolosnya pendanaan proposal PPPUD kami untuk 3 tahun dan juga Pimpinan Politeknik Negeri Sriwjaya yang telah memberikan support atas terlaksananya kegiatan pengabdian PPPUD. Kegiatan ini juga menunjukkan informasi sinergi kerja sama Dikti, Perguruan Tinggi dan masyarakat UMKM sebagai persiapan menghadapi Era 4.0. juga dukungan atas keikut sertaan seminar ini Kiranya kegiatan ini dapat membawa mamfaat bagi kita semua.

\section{REFERENSI}

AriantoWidyanto

,(2006),

BelajarSendiriMikroprosesor

MikrokontrolerMelaluiKomputer

$P C$,PT.Elex Media Komputindo Jakarta
Badan Standardisasi Nasional (2013), Sistem Manajemen Mutu SNI ISO 9001:2008, Penerapan pada UKM, oleh Badan Standardisasi Nasional Jakarta.

Bank Indonesia,(2005), Materi Pelatihan UnitPengembangan Usaha kecil Menengah Untuk Penyusunan Laporan Permohonan Kredit,Proyek Pengembangan Usaha Kecil(SEDP V), Jakarta

Daud, R., \& Windana, V. M. (2014). Pengembangan Sistem Informasi Akuntansi Penjualan Dan Penerimaan Kas Berbasis Komputer Pada Perusahaan Kecil (Studi Kasus Pada Pt. Trust Technology). Jurnal Manajemen dan Bisnis Sriwijaya, (Vol. 12, No. 1).

Heripracoyo, Sulistyo. (2009). Analisis Dan Perancangan Sistem Informasi Akuntansi Pembelian Dan Persediaan Pada PT Oliser Indonesia.Artikel Seminar Nasional Aplikasi Teknologi Informasi 2009 (SNATI 2009), Yogyakarta.

Kai Hwang,( 2000), ArsitekturKomputerLanjut IEEE, London.

Khairurrijal, Munir, M.M. (2004), TeoridanPraktekMikrokontrolerMCS51, InstitutTeknologi Bandung

Manikmas M. Oka Adnyana, (2007), Potensi Pengembangan Usaha Kecil Menengah Dalam Era

Otonomi Daerah, Pusat Penelitian dan Pengembangan Sosial-Ekonomi Pertanian, Bogor

.Malvino, Albert Paul, (2008), PrinsipPrinsipDasarElektronikjilid 2, ElekmediaKomputindo, Jakarta

Mulyani, Widiana, \& Purnama Bambang Eka. (2015). Pembangunan Sistem Informasi Data Balita Pada Posyandu Desa Ploso Kecamatan Punung Kabupaten Pacitan. JurnalSpeed-Sentra

Penelitian 
Engineering dan Edukasi, (Vol. 7, No. 2).

Rachmawati, Rika. (2017). UKM Digital Harus Adopsi Akuntansi TIK. Diakses pada tanggal 3 Maret 2019, dari http://pikiran-rakyat.com/bandungraya/2017/09/11/ukm-digital-harusadopsi-akuntansi-tik-409208.

Rima Silviana. (201)6. Pengaruh pertumbuhan penjualan, profitabilitas, dankebijakan eviden terhadap perubahan laba. Jurnal ilmu dan riset akuntansi.5(1):1-21

Suhersono, Hery. (2005). Desain Bordir Motif Geometris. Jakarta: PT. Gramedia Pustaka Utama
Stalling, William.(2000). Data \& Computer Communications.Prentice International, Inc.

Tabratas, Tharrom-Onno, W Purbo.( 2000). Pengelolahancitrapadamobil robot.Penerbit ITB. Bandung.

Torbjörn Fredriksson Chief, ICT AnalysisSection UNCTAD, Division on Technologyand Logistics (torbjorn.fredriksson@unctad.org)

Workshop on E-Commerce, Development and SMEs 8-9 April 2013 WTO, Geneva, Switzerland.

Vinna, Lim. (2014.)Penjelasan Pengertian Penjualan dan Sistem Penjualan. Diakses pada tanggal 25 Maret 2018, dari http://pusatnyailmu.blogspot.co.id/2014/01/penjelasanpengertian-penjualan-dan.html.

Yulina,Bainil,(2014), Laporan Kegiatan Pelaksanaan IbK di Politeknik Negeri Sriwijaya, PPPM Politeknik Negeri Sriwijaya.Palembang, http://www.antarasumsel.com/berita/30 2266/omzet-umkm-sumselmeningkat,diunduh tanggal 12 Mei 2018 